\title{
MODEL PELATIHAN PARTISIPATIF MELALUI PRAKTIK TERBIMBING DALAM MENINGKATKAN KOMPETENSI MENYUSUN PENELITIAN TINDAKAN KELAS BAGI GURU SMPN 37 KABUPATEN TEBO
}

\author{
ROFA'I \\ SMP Negeri 37 Kabupaten Tebo Provinsi Jambi \\ Email : spdrofai@gmail.com
}

\begin{abstract}
ABSTRAK
Penelitian ini bertujuan untuk mengetahui penggunaan model pelatihan partisipatif melalui praktik terbimbing dalam meningkatkan kompetensi menyusun penelitian tindakan kelas (PTK) bagi guru SMP Negeri 37 Kabupaten Tebo Provinsi Jambi tahun pelajaran 2015/2016. Penelitian Tindakan Sekolah (PTS) ini dilakukan dengan strategi siklus dimulai dari identifikasi masalah, perencanaan, tindakan, observasi, dan refleksi. Tindakan yang dilakukan untuk mengatasi masalah pada siklus 1 adalah menerapkan model pelatihan partisipatif melalui praktik terbimbing secara klasikal dan pada siklus 2 menerapkan model pelatihan partisipatif melalui praktik terbimbing secara individual. Teknik pengumpulan data menggunakan observasi, wawancara dan evaluasi. Analisis data menggunakan analisis deskriptif komparatif. Hasil penelitian menunjukkan bahwa terjadi peningkatan kompetensi guru dalam menyusun proposal penelitian tindakan kelas dari siklus 1 ke siklus 2. Pada siklus 1 penilaian terhadap keenam proposal penelitian tindakan kelas (PTK) yang disampaikan guru dimulai dari latar belakang, rumusan masalah, tujuan penelitian, manfaat penelitian, kajian teoritis, kerangka berpikir, hipotesis, metode penelitian, jadwal penelitian, dan daftar pustaka, masing-masing dinilai dengan kriteria baik (3), cukup (2), dan kurang (1). Pada siklus 2, penilaian terhadap enam proposal yang disampaikan guru semuanya dinilai dengan kriteria baik. Pengamatan terhadap proses pelatihan menunjukkan bahwa guru memiliki keseriusan, kemauan, dan reaktivitas yang tinggi untuk mengembangkan proposal penelitian tindakan Kelas. Partisipasi aktif guru dalam proses pembinaan dan pendampingan intensif baik secara klasikal maupun individu mendukung keberhasilan penelitian tindakan sekolah ini sehingga guru dapat menyusun proposal penelitian tindakan Kelas dengan kriteria baik.
\end{abstract}

Kata Kunci: pelatihan partisipatif, praktik terbimbing, kompetensi menyusun penelitian tindakan Kelas.

\section{PENDAHULUAN}

Guru memiliki peran yang strategis dalam upaya meningkatkan kualitas pendidikan sehingga ada slogan no teacher, no education yang berarti tidak ada guru, tidak ada pendidikan. Dengan kata lain guru merupakan komponen kunci dalam upaya peningkatan kualitaspendidikan dan menjadi salah satu penentu keberhasilan pendidikan. Hal ini sangat wajar karena guru yang secara langsung berinteraksi edukatif dengan siswa, sehingga berbagai permasalahan yang ada dalam pembelajaran dapat langsung diketahui oleh guru untuk dicarikan solusi pemecahannya. Menurut Thomas E. Curtis dan Wilma W. Bidwell dalam Zein (2016) bahwa proses pembelajaran di sekolah (kelas) peranan guru lebih spesifik sifatnya dalam pengertian yang sempit, yakni dalam hubungan proses belajar mengajar. Peranan guru adalah sebagai pengorganisasi lingkungan belajar dan sekaligus sebagai fasilitator belajar.

Manizar (2015) menyatakan bahwa dalam rangka pengembangan profesional, guru tidak bisa melepaskan dirinya dari kegiatan akademik penelitian. Penelitian yang terkait langsung dengan tugas pokok dan fungsinya serta berdampak langsung terhadap peningkatan kualitas pembelajaran adalah penelitian tindakan kelas. Dalam kegiatan penelitian ini, guru memiliki peran strategis dalam pengembangan kompetensi profesional sekaligus sebagai upaya dalam meningkatkan dan memperbaiki proses maupun hasil belajar siswa.

Saat ini penelitian tindakan kelas (PTK) memang mendapatkan perhatian yang cukup besar dalam dunia pendidikan. PTK bahkan merupakan ikon khusus dari program pemerintah dalam upaya peningkatan kualitas guru dan tenaga kependidikan pada umumnya (Sanjaya, 
2016). Pemerintah juga secara khusus setiap tahun memberikan dana bagi guru yang mampu merencanakan dan melakukan PTK dengan baik (Depdiknas, 2008). PTK menjadi semakin mendapatkan prioritas untuk bisa dilakukan guru, mengingat adanya manfaat ganda dari PTK. Pertama, pelaksanaan PTK yang terencana dan terkendali secara baik, akan meningkatkan kinerja guru dalam mengelola pembelajaran yang berkualitas (Ar, 2014). Dengan kata lain, pelaksanaan PTK akan meningkatkan kompetensi guru, yang saat ini sedang menjadi isu utama dalam peningkatan mutu pendidikan nasional. Kedua, penyelesaian masalah kelas atau pembelajaran akan memberikan perbaikan pada kualitas proses pembelajaran. Ketiga, perbaikan peran guru dalam pembelajaran akan mampu memberikan kontribusi bagi peningkatan kualitas pendidikan secara nasional. Hal ini sesuai dengan pendapat Ananda, dkk (2015) yang menyatakan bahwa PTK sangat mendukung program peningkatan kualitas pembelajaran di sekolah, yang muaranya adalah peningkatan kualitas pendidikan.

PTK disamping memberikan manfaat bagi peningkatan kualitas pembelajaran/pendidikan, laporan PTK juga sangat bermanfaat bagi guru yang bersangkutan dalam hal kenaikan pangkat dan kredit pengembangan profesi keguruan. Hal ini sesuaiPeraturan Bersama Mendiknas dan Kepala BAKN Nomor 03/V/PB/2010 dan Nomor 14 Tahun 2010 tanggal 6 Mei 2010 yang mulai berlaku efektif pada tanggal 1 Januari 2013 bahwa syarat kenaikan pangkat/jabatan guru dari III/b ke pangkat jabatan lebih tinggi wajib melaksanakan kegiatan pengembangan diri dan publikasi ilmiah yang antara lain dari hasil PTK (Prihantoro, 2019). Disamping itu, selaras dengan kebijakan sertifikasi guru, karya pengembangan profesi dalam bentuk PTK juga merupakan salah satu butir penting penentu keberhasilan guru dalam meraih sertifikasi. Dengan demikian, kegiatan meneliti maupun menulis, mau tidak mau, suka tidak suka, harus dilakukan oleh guru (Hanifah, 2014).

Guru sebagai peneliti (Darmadi, 2016) agar dapat melaksanakan PTK dengan baik perlu menyusun rencana penelitian dalam bentuk proposal PTK. Di dalam proposal PTK ini antara lain dijelaskan tentang diagnosis dan penetapan masalah yang ingin diselesaikan, bentuk dan skenario tindakan, pengembangan instrumen untuk mengukur keberhasilan tindakan, serta prosedur analisis dan interpretasi data penelitian. Berdasar proposal inilah penelitian dilaksanakan. Namun demikian kenyataan di sekolah menunjukkan bahwa masih banyak guru yang kurang memahami PTK dan mengalami kesulitan dalam menyusun proposal PTK. Keadaan seperti ini juga terjadi pada guru-guru di SMP Negeri 37 Kabupaten Tebo Provinsi Jambi. Hasil wawancara penulis dengan kepala sekolah di SMP Negeri 37 Tebo menunjukkan bahwa banyak guru yang mengalami kesulitan dalam menyusun proposal PTK dan melaksanakannya di kelas (wawancara tanggal 14 dan 15 Maret 2016). Pada dasarnya hal ini disebabkan oleh faktor terbatasnya pengetahuan guru tentang rambu-rambu penyusunan proposal PTK baik yang menyangkut diagnosis dan penetapan masalah, bentuk dan skenario tindakan, maupun prosedur pelaksanaan PTK. Selanjutnya berdasarkan wawancara dengan beberapa orang guru khususnya guru mata pelajaran Ilmu Pengetahuan Sosial (IPS), Pendidikan Pancasila dan Kewarganegaraan (PPKn) di SMP Negeri 37 Kabupaten Tebo yang sudah pernah mengikuti pelatihan PTK (wawancara tanggal 14 dan15 Agustus 2016), ternyata mereka masih mengalami kesulitan dalam menyusun proposal PTK seperti dalam menyusun latar belakang, menyusun kerangka teori, dan menyusun skenario pembelajaran berdasarkan variabel tindakan yang telah ditetapkan. Lemahnya kemampuan mereka dalam menyusun proposal PTK disebabkan oleh keterbatasan pengetahuan atau pemahaman mereka tentang PTK secara praktek. Pelatihan penelitian tindakan kelas yang pernah diikuti hanya sebatas memberikan pemahaman terhadap konsep dasar penelitian tindakan kelas saja. Hal ini juga didukung oleh hasil wawancara Farida. (2015) dengan guru-guru di Provinsi Sulawesi Selatan yang pernah mengikuti pelatihan PTK. Hasil wawancara tersebut menyatakan bahwa guru kurang dilatih tentang cara-cara mendiagnosis masalah pembelajaran sendiri, menemukan penyebab utama masalah, dan melakukan terapi terhadap masalah pembelajarannya secara sistematis, terkendali, serta terprogram. Jadi dalam pelatihan PTK tersebut mengindikasikan bahwa pelatih hanya mentransfer pengetahuan tentang penelitian tindakan kelas dan belum melatih 
kompetensi guru dalam menyusun rencana penelitian tindakan kelas untuk memperbaiki kualitas pembelajarannya. Kesulitan guru-guru dalam menyusun proposal PTK tersebut, disamping disebabkan oleh keterbatasan pengetahuan atau pemahaman mereka tentang PTK secara praktek, juga disebabkan oleh tidak adanya pembimbing/pendamping yang dapat mengarahkan dan memberikan motivasi kepada mereka untuk menyusun proposal PTK. Ketiadaan pembimbing menyebabkan mereka tidak percaya diri dan tidak berani mencoba karena tidak yakin proposal yang mereka akan susun adalah benar.

Mengingat pentingnya PTK bagi pengembangan profesi guru, namun dalam kenyataan guru-guru di SMP Negeri 37 Kabupaten Tebo masih mengalami kesulitan dalam menyusun proposal PTK sebagai tahap persiapan penelitian, maka kepala sekolah sebagai pihak yang memegang peranan penting dalam peningkatan kualitas pendidikan di sekolah perlu mengatasi permasalahan tersebut. Upaya untuk meningkatkan kompetensi guru- guru di SMP Negeri 37 Kabupaten Tebo dalam menyusun proposal PTK ini perlu dilakukan dengan memberikan pelatihan PTK yang sesuai dengan kebutuhan guru, melibatkan guru secara aktif dalam perencanaan, pelaksanaan, dan menilai hasil pelatihan, serta mendampingi secara intensif guruguru tersebut hingga mampu menyusun atau menghasilkan proposal PTK dengan baik. Pelatihan dengan model partisipatif dan pendampingan intensif inilah yang dianggap tepat untuk meningkatkan kompetensi guru dalam menyusun proposal PTK. Sesuai dengan penjelasan Fitria, dkk (2019) bahwa dalam penerapan model pelatihan partisipatif, kegiatan belajar dalam pelatihan dibangun atas dasar keikutsertaan peserta pelatihan dalam semua aspek kegiatan mulai dari kegiatan merencanakan, melaksanakan, sampai pada tahap menilai kegiatan pembelajaran dalam pelatihan. Upaya yang dilakukan pelatih pada prinsipnya lebih ditekankan pada memotivasi dan melibatkan kegiatan peserta pelatihan. Oleh karena itu model pelatihan ini dianggap lebih efektif karena guru-guru dilibatkan secara aktif berlatih dan berkarya menghasilkan proposal PTK tidak hanya mendengarkan ceramah yang hanya bersifat transfer pengetahuan, didampingi pelatih yang selalu mengarahkan dan memotivasi hingga guru-guru mampu menyusun proposal PTK yang merupakan hasil refleksi dari permasalahan pembelajaran di kelasnya. Hal ini juga sejalan dengan penjelasan Mediatati, dkk (2015) yang menyatakan bahwa penggunaan model partisipatif dalam pelatihan dipandang lebih efektif karena yang menjadi sasaran utamanya adalah guru yang pada umumnya sudah memiliki pengetahuan. Penelitian Hamdani (2018) tentang implementasi model pelatihan PTK Reflektif Berbasis Kompetensi juga menunjukkan bahwa model pelatihan yang pada prinsipnya menekankan pada partisipasi guru-guru dapat meningkatkan kemampuan guru-guru dalam menyusun proposal PTK berdasarkan hasil refleksi terhadap pembelajarannya. Disamping itu pembimbingan/pendampingan secara langsung dan intensif dapat mengoptimalkan kemampuan guru-guru dalam menyusun proposal PTK, sebagaimana ditunjukkan oleh hasil penelitian Pianda (2018) yang menyatakan bahwa metode tutorial yang diterapkan pada proses pembelajaran Diklat PTK dapat mengoptimalkan kemampuan guruguru dalam menyusun proposal PTK.

Penelitian Tindakan Sekolah ini difokuskan pada upaya meningkatkan kompetensi menyusun proposal PTK bagi guru-guru di SMP Negeri 37 Kabupaten Tebo melalui penerapan model pelatihan partisipatif dengan pendampingan intensif. Permasalahan yang hendak dijawab adalah apa saja kesulitan yang dihadapi guru-guru dalam menyusun proposal PTK dan bagaimana penerapan model pelatihan partisipatif dengan pendampingan intensif untuk meningkatkan kompetensi guru-guru dalam menyusun proposal PTK serta bagaimana hasil penerapan model pelatihan tersebut.Sesuai dengan permasalahan maka tujuan dari penelitian ini adalah untuk mendeskripsikan kesulitan yang dihadapi guru-guru dalam menyusun proposal PTK dan penerapan model pelatihan partisipatif dengan pendampingan intensif untuk meningkatkan kompetensi guru-guru dalam menyusun proposal PTK serta hasil dari penerapan model pelatihan tersebut. Hasil penelitian ini diharapkan memberikan manfaat bagi guru, yaitu menumbuhkan motivasi dalam menyusun proposal PTK dan melaksanakan PTK, serta bagi sekolah dapat meningkatkan kinerja sekolah melalui peningkatan profesionalisme guru. 


\section{METODE PENELITIAN}

Penelitian ini adalah Penelitian Tindakan Sekolah (PTS), yang dilaksanakan dengan strategi siklus dimulai dari identifikasi masalah, penyusunan rencana tindakan, pelaksanaan tindakan, observasi, dan refleksi. Penelitian ini dilakukan dalam dua siklus, siklus pertama dilakukan dalam empat kali pertemuan (satu kali per minggu) dan siklus kedua dilakukan dalam tiga kali pertemuan, mulai bulan Agustus sampai September 2016. Tempat penelitian di SMP Negeri 37 Tebo dengan subyek penelitian guru-guru di SMP Negeri SMP Negeri 37 Teboyang terdiri dari 1 orang guru IPS, 1 orang guru PPKn, 1 orang guru Pendidikan Agama Islam, 1 Orang Guru Penjaskes dan 2 orang guru Bahasa Indonesia. Teknik pengumpulan data menggunakan wawancara untuk memperoleh data tentang kesulitan guru dalam menyusun proposal PTK, observasi untuk mengamati implementasi model pelatihan partisipatif melalui praktik terbimbing, dan evaluasi terhadap proposal PTK untuk memperoleh data keberhasilan dari implementasi model pelatihan. Teknik analisis data menggunakan analisis deskriptif komparatif. Indikator keberhasilan penelitian adalah guru mampu menghasilkan proposal PTK dengan kriteria baik.

\section{HASIL DAN PEMBAHASAN}

Sebelum dilakukan pelatihan guru-guru menyatakan masih mengalami kesulitan dalam menyusun proposal PTK sebagai tahap persiapan dalam melaksanakan PTK sesuai ramburambu penyusunan proposal baik dari segi isi maupun kebahasaan/pengkalimatan. Kesulitan menyusun proposal PTK tersebut mencakup semua aspek dari Bab I sampai Bab III. Aspek dari Bab I meliputi merumuskan judul penelitian, latar belakang masalah, rumusan masalah, tujuan penelitian, dan manfaat hasil penelitian. Aspek dari Bab II meliputi pemaparan kajian teoritis/pustaka, kerangka berpikir, dan hipotesis tindakan. Aspek dari Bab III metode penelitian meliputi pemaparan tentang jenis, lokasi, dan subyek penelitian; prosedur penelitian dari setiap siklus mulai perencanaan, tindakan, observasi, refleksi, dan jadwal penelitian; sumber data, cara pengambilan data, instrumen, dan pengolahan data; serta indikator keberhasilan penelitian. Kesulitan dalam menyusun proposal ini disebabkan karena guru-guru belum memiliki pemahaman yang jelas tentang PTK dan cara menyusun proposal PTK yang benar, serta tidak berani mencoba karena takut salah.

Setelah dilakukan pelatihan menggunakan model partisipatif melalui praktik terbimbing secara klasikal (tindakan pada siklus 1) guru-guru mulai mampu menyusun proposal PTK sesuai rambu-rambu penyusunan proposal baik dari aspek isi maupun kebahasaan/pengkalimatan walaupun dengan kriteria penilaian yang berbeda. Pada awal pelaksanaan pelatihan kepada guru-guru terlebih dahulu diberikan dan dijelaskan materi tentang konsep PTK dan cara menyusun proposal PTK oleh pakar/pelatih dengan metode pembelajaran partisipatif tidak hanya ceramah tetapi lebih menekankan pada tanya jawab, diskusi dan pemberian contoh-contoh yang aplikatif. Kemudian dilanjutkan dengan kegiatan menyusun rencana awal PTK dan proposal PTK dengan pembimbingan/pendampingan secara kelompok/klasikal dari pelatih, hingga proposal PTK yang disusun oleh guru tersebut siap dipresentasikan. Selama proses penyusunan proposal PTK tetap diupayakan terbentuknya interaksi antar guru-guru dan antara guru-guru dengan pendamping dalam bentuk diskusi, tanya jawab, pengarahan dan motivasi. Semua peserta tampak antusias, serius, tekun, dan aktif mengikuti kegiatan pelatihan hingga berhasil menyusun proposal PTK. Hal ini ditunjukkan oleh semua guru sebagai peserta pelatihan berhasil menyusun proposal PTK mulai Bab I sampai Bab III sesuai rambu-rambu penyusunan proposal PTK, walaupun masih ada kekurangan atau kesalahan di bagian/aspek tertentu dari Bab I, Bab II, dan Bab III tersebut. Namun demikian apabila dibandingkan dengan kondisi awal sebelum dilakukan tindakan pelatihan dimana guruguru menyatakan masih kesulitan dalam menyusun proposal ternyata setelah diberikan pelatihan dengan model partisipatif dan pendampingan intensif menunjukkan bahwa guru-guru sudah mulai mempunyai pemahaman yang cukup baik tentang proposal PTK sehingga mampu 
menyusun proposal PTK sesuai rambu-rambu penyusunan proposal walaupun dengan kriteria penilaian yang berbeda yaitu baik, cukup, dan kurang. Aspek yang dinilai meliputi 10 aspek dengan masing-masing aspek terdiri dari empat deskriptor yaitu latar belakang masalah, rumusan masalah, tujuan penelitian, manfaat hasil penelitian, kajian teoritis/pustaka, kerangka berpikir, hipotesis tindakan, metode penelitian, jadwal penelitian, dan daftar pustaka. Tiga orang guru mendapat nilai rata-rata 3,9; 3,8; 3,7 dengan kriteria baik. Aspek yang kurang adalah kajian teoritis/pustaka yang belum memaparkan hasil penelitian terdahulu yang relevan dan menunjukkan kontribusinya pada penelitian yang dilakukan, serta daftar pustaka tidak hanya menulis sumber yang dirujuk dan ada sumber rujukan yang tidak ditulis. Selanjutnya dua orang guru mendapat nilai rata-rata 2,6 dan 2,2 dengan kriteria cukup. Aspek yang kurang adalah pada:

(1) latar belakang masalah yang belum memaparkan pilihan tindakan yang didukung sumber pustaka dan pemaparan analisis masalah sampai tindakan belum sistematis; (2) rumusan masalah yang belum dirumuskan secara singkat dan jelas menyatakan permasalahan dan tindakan yang diusulkan; (3) tujuan penelitian belum dirumuskan secara singkat dan jelas sesuai dengan permasalahan; (4) kajian teoritis/pustaka yang belum memaparkan teori-teori yang relevan dan hasil penelitian terdahulu yang relevan; (5) kerangka berpikir belum dipaparkan dalam bentuk bagan; (6) jadwal penelitian hanya memuat waktu pelaksanaan penelitian; dan (7) daftar pustaka belum dicantumkan. Kemudian satu orang guru mendapat nilai rata-rata 1,8 dengan kriteria kurang. Aspek yang kurang adalah pada: (1) latar belakang masalah yang belum memaparkan pilihan tindakan yang didukung sumber pustaka dan pemaparan analisis masalah sampai tindakan belum sistematis; (2) rumusan masalah yang belum dirumuskan secara singkat dan jelas menyatakan permasalahan dan tindakan yang diusulkan; (3) tujuan penelitian belum dirumuskan secara singkat dan jelas sesuai dengan permasalahan; (4) kajian teoritis/pustaka yang belum memaparkan teori-teori yang relevan dan hasil penelitian terdahulu yang relevan; (5) kerangka berpikir belum dipaparkan sama sekali; (6) hipotesis tindakan dirumuskan melebihi permasalahan; (7) jadwal penelitian hanya memuat waktu pelaksanaan penelitian; dan (8) daftar pustaka belum dicantumkan. Untuk perumusan judul penelitian semuanya benar baik dari segi isi maupun pengkalimatannya. Adapun hasil penilaian terhadap proposal PTK guruguru secara terperinci dapat dilihat dalam tabel berikut ini.

Tabel 1. Hasil Penilaian Proposal PTK Guru-Guru Pada Siklus 1

\begin{tabular}{|c|c|c|c|c|c|c|c|}
\hline No & Aspek penilaian dan deskriptor & $\mathbf{A}$ & B & $\mathbf{C}$ & $\mathbf{D}$ & $\mathbf{E}$ & $\mathbf{F}$ \\
\hline 1. & $\begin{array}{l}\text { Latar Belakang Masalah } \\
\text { a. Dipaparkan kondisi ideal dan kondisi nyata } \\
\text { pembelajaran yang diteliti dengan bukti } \\
\text { pendukung } \\
\text { b. Ada masalah dan analisis masalah yang } \\
\text { menghasilkan penyebab-penyebab terjadinya } \\
\text { masalah } \\
\text { c. Ada tindakan yang dipilih untuk mengatasi } \\
\text { masalah yang didukung sumber pustaka } \\
\text { d. Pemaparan analisis masalah sampai tindakan } \\
\text { yang dipilih diuraikan secara sistematis dan } \\
\text { mudah dipahami }\end{array}$ & 4 & 4 & 4 & 3 & 2 & 2 \\
\hline
\end{tabular}




\begin{tabular}{|c|c|c|c|c|c|c|c|}
\hline 2. & $\begin{array}{l}\text { Rumusan Masalah } \\
\text { a. Rumusan masalah menggunakan kalimat } \\
\text { tanya } \\
\text { b. Rumusan masalah singkat dan jelas } \\
\text { c. Rumusan masalah berisi secara jelas } \\
\text { menyatakan masalah penelitian } \\
\text { d. Rumusan masalah menyebutkan alternatif } \\
\text { tindakan yang diusulkan }\end{array}$ & 4 & 4 & 4 & 3 & 1 & 1 \\
\hline 3. & $\begin{array}{l}\text { Tujuan Penelitian } \\
\text { a. Tujuan dirumuskan secara singkat } \\
\text { b. Tujuan dirumuskan secara jelas } \\
\text { c. Tujuan dirumuskan berdasarkan } \\
\text { permasalahan yang dikemukakan } \\
\text { d. Tujuan dirumuskan berdasarkan cara } \\
\text { pemecahan masalah yang dikemukakan }\end{array}$ & 4 & 4 & 4 & 3 & 1 & 1 \\
\hline 4. & $\begin{array}{l}\text { Manfaat Hasil Penelitian } \\
\text { a. Manfaat hasil penelitian diuraikan secara jelas } \\
\text { b. Manfaat hasil penelitian berkenaan dengan } \\
\text { perbaikan kualitas pembelajaran } \\
\text { c. Manfaat hasil penelitian menyebutkan subjek } \\
\text { yang akan mendapat manfaat (misalnya guru, } \\
\text { siswa, komponen sekolah yang lain) } \\
\text { d. Manfaat hasil penelitian mengemukakan } \\
\text { inovasi yang akan dihasilkan dari penelitian }\end{array}$ & 4 & 4 & 4 & 4 & 4 & 4 \\
\hline 5. & $\begin{aligned} \text { Kajian Teoritis/Pustaka } \\
\text { a. Memaparkan kajian teoritis berkenaan dengan } \\
\text { pembelajaran yang diteliti } \\
\text { b. Memaparkan kajian teoretis berkenaan } \\
\text { dengan tindakan yang dipilih } \\
\text { c. Memaparkan teori-teori yang relevan dengan } \\
\text { pembelajaran yang diteliti dan tindakan yang } \\
\text { dipilih } \\
\text { d. Memaparkan hasil penelitian terdahulu yang } \\
\text { relevan dan menunjukkan kontribusinya pada } \\
\text { penelitian yang dilakukan }\end{aligned}$ & 3 & 3 & 3 & 2 & 2 & 2 \\
\hline 6. & $\begin{array}{l}\text { Kerangka Berpikir } \\
\text { a. Kerangka berpikir disusun berdasarkan kajian } \\
\text { teoretis } \\
\text { dan empiris } \\
\text { b. Kerangka berpikir menunjukkan keterkaitan } \\
\text { antara masalah, teori, hasil penelitian } \\
\text { terdahulu yang relevan, pilihan tindakan. } \\
\text { c. Kerangka berpikir dipaparkan dalam bentuk } \\
\text { uraian argumentatif (kalimat/paragraf) }\end{array}$ & 4 & 4 & 4 & 3 & 3 & - \\
\hline
\end{tabular}




\begin{tabular}{|c|c|c|c|c|c|c|c|}
\hline & $\begin{array}{l}\text { d. Kerangka berpikir dipaparkan dalam bentuk } \\
\text { bagan/diagram }\end{array}$ & & & & & & \\
\hline 7. & $\begin{array}{l}\text { Hipotesis Tindakan } \\
\text { a. Hipotesis tindakan berupa pernyataan singkat } \\
\text { yang disimpulkan dari landasan teori } \\
\text { b. Hipotesis tindakan memuat pembelajaran yang } \\
\text { diteliti } \\
\text { c. Hipotesis tindakan memuat tindakan yang } \\
\text { diusulkan } \\
\text { d. Hipotesis tindakan memuat subjek dan lokasi } \\
\text { penelitian }\end{array}$ & 4 & 4 & 4 & 3 & 4 & 3 \\
\hline 8. & $\begin{array}{l}\text { Metode Penelitian } \\
\text { a. Dipaparkan jenis penelitian, lokasi dan } \\
\text { subyek penelitian } \\
\text { b. Dipaparkan prosedur penelitian dari setiap } \\
\text { siklus mulai perencanaan, pelaksanaan, } \\
\text { observasi, dan refleksi } \\
\text { c. Dipaparkan instrumen, sumber data, cara } \\
\text { pengambilan data, serta pengolahan data } \\
\text { d. Dipaparkan indikator keberhasilan penelitian }\end{array}$ & 4 & 4 & 4 & 4 & 4 & 4 \\
\hline 9. & $\begin{array}{l}\text { Jadwal Penelitian } \\
\text { a. Jadwal penelitian memuat kegiatan dan waktu } \\
\text { pelaksanaan kegiatan } \\
\text { b. Kegiatan yang ditampilkan memuat kegiatan } \\
\text { tahap persiapan penelitian } \\
\text { c. Kegiatan yang ditampilkan memuat kegiatan } \\
\text { tahap pelaksanaan penelitian } \\
\text { d. Kegiatan yang ditampilkan memuat kegiatan } \\
\text { tahap pelaporan penelitian }\end{array}$ & 4 & 4 & 4 & 1 & 1 & 1 \\
\hline 10. & $\begin{array}{l}\text { Daftar Pustaka/Daftar Rujukan } \\
\text { a. Tiap butir pustaka/rujukan ditulis sesuai } \\
\text { dengan aturan penulisan rujukan } \\
\text { b. Daftar pustaka disusun secara alfabetis } \\
\text { c. Sumber yang ditulis hanyalah sumber yang } \\
\text { dirujuk }\end{array}$ & 4 & 3 & 2 & - & - & - \\
\hline & $\begin{array}{l}\text { d. Tidak ada sumber rujukan yang tertinggal/ } \\
\text { tidak ditulis dalam daftar pustaka }\end{array}$ & & & & & & \\
\hline & Nilai rata-rata & 3,9 & 3,8 & 3,7 & 2,6 & 2,2 & 1,8 \\
\hline
\end{tabular}


Keterangan:

Penilaian proposal penelitian tindakan kelas dilakukan dengan memberikan skor pada setiap aspek penilaian. Skor berkisar antara 1 sampai dengan 4. Pemberian skor dilakukan dengan ketentuan sebagai berikut:

a. Skor 4 diberikan apabila 4 buah deskriptor pada aspek yang bersangkutan muncul/tampak.

b. Skor 3 diberikan apabila 3 buah deskriptor pada aspek yang bersangkutan muncul/tampak.

c. Skor 2 diberikan apabila 2 buah deskriptor pada aspek yang bersangkutan muncul/tampak.

d. Skor 1 diberikan apabila 1 buah deskriptor pada aspek yang bersangkutan muncul/tampak.

Nilai rata-rata: $>3,00-4,00=$ baik; $>2,00-<3,00=$ cukup; $1,00-<2,00=$ kurang

Agar kekurangan atau kesalahan dalam menyusun bagian-bagian tertentu dari proposal PTK tersebut dapat diperbaiki sehingga guru-guru dapat menghasilkan proposal PTK dengan kriteria baik maka dilakukan tindakan perbaikan pada siklus II. Tindakan yang diusulkan berdasarkan hasil refleksi adalah dengan pendampingan/pembimbingan intensif secara individual kepada setiap peserta dalam merevisi proposal PTK hasil dari tindakan siklus I. Melalui pendampingan intensif secara individual kepada setiap peserta diharapkan masingmasing guru dapat lebih memahami dan mengetahui secara detail bagian-bagian mana dari proposalnya yang harus diperbaiki dan dilengkapi serta bagaimana perbaikannya. Disamping itu kepada guru-guru diberikan contoh-contoh laporan PTK dan cara mencari jurnal penelitian yang layak dirujuk untuk memberikan pemahaman yang lebih jelas dalam merevisi proposal PTKnya.

Hasil tindakan dari siklus 2, menunjukkan bahwa kemampuan guru-guru dalam menyusun proposal PTK makin meningkat. Kekurangan dan kesalahan dalam menyusun bagianbagian tertentu dari Bab I sampai Bab III baik dari segi isi maupun kebahasaan/pengkalimatan bisa diperbaiki dan dilengkapi. Mulai Bab I kekurangan dalam latar belakang masalah yang belum memaparkan pilihan tindakan yang didukung sumber pustaka dan pemaparan analisis masalah sampai tindakan belum sistematis, sudah dapat dilengkapi dan diuraikan secara sistematis, rumusan masalah sudah dirumuskan secara singkat dan jelas menyatakan permasalahan dan tindakan yang diusulkan, tujuan penelitian sudah dirumuskan secara singkat dan jelas sesuai dengan permasalahan. Bab II, kajian teoritis/pustaka sudah memaparkan teoriteori yang relevan dan hasil penelitian terdahulu yang relevan, kerangka berpikir sudah dipaparkan dalam bentuk paragraf dan bagan, hipotesis tindakan sudah dirumuskan sesuai permasalahan. Disamping itu juga dalam menulis sumber kutipan dalam kajian teori guru sudah menggunakan cara yang benar. Guru-guru berupaya mencari/meminjam dan membaca buku pustaka serta membuka internet untuk melengkapi Bab II ini dibantu oleh pendamping. Bab III, jadwal penelitian sudah dilengkapi dengan memuat waktu dan kegiatan penelitian. Daftar pustaka sudah dicantumkan semuanya. Hasil penilaian terhadap proposal PTK yang dipresentasikan keenam guru, dari 10 aspek yang dinilai semua deskriptor sudah terpenuhi. Keenam proposal PTK mendapat nilai rata-rata 4 dengan kriteria baik, yang dapat dilihat dalam tabel berikut ini.

Tabel 2. Hasil Penilaian Proposal PTK Guru-Guru Pada Siklus 2

\begin{tabular}{lccccccc}
\hline No & Aspek penilaian dan deskriptor & A & B & C & D & E & F \\
1. & Latar Belakang Masalah & 4 & 4 & 4 & 4 & 4 & 4 \\
2. & Rumusan Masalah & 4 & 4 & 4 & 4 & 4 & 4 \\
3. & Tujuan Penelitian & 4 & 4 & 4 & 4 & 4 & 4 \\
\hline
\end{tabular}




\begin{tabular}{llllllll}
\hline 4. & Manfaat Hasil Penelitian & 4 & 4 & 4 & 4 & 4 & 4 \\
5. & Kajian Teoritis/Pustaka & 4 & 4 & 4 & 4 & 4 & 4 \\
6. & Kerangka Berpikir & 4 & 4 & 4 & 4 & 4 & 4 \\
7. & Hipotesis Tindakan & 4 & 4 & 4 & 4 & 4 & 4 \\
8. & Metode Penelitian & 4 & 4 & 4 & 4 & 4 & 4 \\
$9 . \quad$ & 4 & 4 & 4 & 4 & 4 & 4 \\
$10 . \quad$ & Jadwal Penelitian & 4 & 4 & 4 & 4 & 4 & 4 \\
& Daftar Pustaka/Daftar Rujukan & 4 & 4 & 4 & 4 & 4 & 4 \\
\hline
\end{tabular}

Catatan: Nilai rata-rata: $>3,00-4,00=$ baik; $>2,00-<3,00=$ cukup; $1,00-<2,00=$ kurang

Jadi ada peningkatan kemampuan/kompetensi guru-guru dalam menyusun proposal PTK dari siklus 1 ke siklus 2. Siklus 1 keenam proposal PTK yang dihasilkan guru dinilai dengan kriteria baik (3), kriteria cukup (2), kriteria kurang (1). Pada siklus 2 keenam proposal PTK yang dihasilkan guru semuanya dinilai dengan kriteria baik.

\section{Pembahasan}

Model pelatihan partisipatif melalui praktik terbimbing ini prinsipnya adalah melibatkan guru-guru semaksimal mungkin dalam pelatihan mulai identifikasi kebutuhan, perencanaan, pelaksanaan, sampai evaluasi pelatihan. Jadi pelatihan ini diselenggarakan berdasarkan kebutuhan guru, direncanakan, dilaksanakan, dan dievaluasi dengan melibatkan partisipasi aktif dari guru-guru, agar hasilnya betul-betul sesuai dengan kebutuhan dan harapan guru. Jadi dalam semua tahapan pelatihan lebih menekankan pada pembelajaran partisipatif. Hal ini sesuai dengan pendapat Djuju Sudjana (1993:14) bahwa model pelatihan partisipatif lebih menekankan pada kegiatan pembelajaran partisipatif yang tinggi yang berarti mengikutsertakan guru semaksimal mungkin dalam proses pelatihan. Upaya yang dilakukan pelatih pada prinsipnya lebih ditekankan pada motivasi dan melibatkan kegiatan peserta. Model pelatihan partisipatif ini juga dipandang lebih efektif karena yang menjadi sasaran utamanya adalah guru (orang dewasa) yang pada umumnya sudah memiliki pengetahuan (Knowles, 1984:44).

Penggunaan model pelatihan partisipatif melalui praktik terbimbingsecara kelompok/klasikal maupun secara individual telah dapat mengatasi permasalahan kesulitan guru dalam menyusun proposal PTK. Minat, rasa percaya diri, dan kompetensi guru-guru dalam menyusun proposal PTK semakin meningkat. Melalui pendampingan intensif dari pelatih, guruguru berani mencoba dan tidak takut salah dalam menyusun proposal PTK, sehingga guruguru dapat menghasilkan proposal PTK (Bab I sampai dengan Bab III) yang akan diimplementasikan dalam penelitian di sekolahnya dengan kriteria baik berdasarkan 10 aspek yang dinilai. Hal ini sesuai dengan pendapat Cain dan Comings dalam Badu (2012:44) yang menyatakan bahwa peran pelatih dalam pembelajaran partisipatif adalah sebagai fasilitator yang harus memaksimalkan kinerja peserta pelatihan. Guru-guru merespon positif pelatihan dengan model partisipatif melalui praktik terbimbingini karena pelatihan ini memberikan waktu dan bimbingan yang cukup yang mereka butuhkan untuk menyusun sebuah proposal penelitian yang baik serta benar-benar bermanfaat dalam membangun pengetahuan dan pemahaman mereka tentang konsep-konsep penelitian tindakan kelas dan menyusun proposal PTK. Hasil penelitian ini mendukung dan menambah temuan penelitian sebelumnya dari Nitiasih (2010) yang menunjukkan adanya peningkatan kemampuan guru-guru dalam membuat proposal PTK melalui implementasi model pelatihan PTK Reflektif Berbasis Kompetensi karena model pelatihan ini pada prinsipnya menekankan pada partisipasi guru-guru untuk membuat proposal PTK berdasarkan hasil refleksi terhadap pembelajarannya. Kemudian penelitian dari Budi Martono (2009) yang menunjukkan bahwa melalui metode tutorial atau 
pembimbingan/pendampingan secara langsung dapat mengoptimalkan kemampuan peserta Diklat PTK dalam menyusun proposal PTK.

\section{KESIMPULAN}

Berdasarkan hasil penelitian dan pembahasan yang telah dilakukan, maka diperoleh beberapa simpulan sebagai berikut : (1) Guru-guru di SMP Negeri 37 Tebo mengalami kesulitan dalam menyusun proposal PTK mulai dari perumusan latar belakang masalah, rumusan masalah, tujuan penelitian, manfaat hasil penelitian, kajian teori/pustaka, kerangka berpikir, hipotesis tindakan dan metode penelitian baik dari aspek isi maupun kebahasaan/pengkalimatan, karena guru-guru belum memiliki pemahaman yang jelas tentang konsep PTK dan aplikasinya dalam penyusunan proposal PTK, (2) Penerapan model pelatihan partisipatif melalui praktik terbimbing dapat meningkatkan kompetensi menyusun proposal PTK dari guru-guru di SMP Negeri 37 Tebo, yang dapat dilihat dari hasil karya guru yaitu proposal PTK yang semuanya dinilai dengan kategori baik,

Dari hasil simpulan tersebut, dapat diberikan beberapa saran sebagai berikut (1) Bagi sekolah, agar melaksanakan pelatihan sejenis sebagai tindak lanjut untuk meningkatkan kompetensi guru-guru di SMP Negeri 37 Tebo dalam melaksanakan PTK dan menyusun laporan PTK dalam bentuk jurnal, yang bermanfaat bagi peningkatan kualitas pembelajaran dan profesionalitas guru. Disamping itu bisa dilaksanakan pelatihan dengan model tutor sebaya untuk guru-guru mata pelajaran yang lain, (2) Bagi guru, agar proposal PTK yang telah disusun diimplementasikan dalam penelitian di sekolah/kelasnya, disusun laporannya dalam bentuk jurnal sehingga bermanfaat bagi peningkatan kepangkatan atau jabatan fungsional guru. Disamping itu diharapkan guru-guru menjadi terbiasa untuk menyusun proposal PTK dan mengimplementasikan dalam penelitian di kelasnya sebagai pelaksanaan tugas profesinya serta menularkan kemampuannya tersebut kepada guru-guru mata pelajaran lain, (3) Bagi sekolah lain, hasil penelitian ini dapat dijadikan sebagai bahan/masukan untuk melaksanakan pelatihan dengan model yang sejenis untuk meningkatkan kompetensi guru-guru dalam melakukan PTK.

\section{DAFTAR PUSTAKA}

Ananda, R., Rafida, T., \& Syahrum, S. (2015). Penelitian tindakan kelas. Bandung: Citapustaka Media

Darmadi, H. (2016). Tugas, peran, kompetensi, dan tanggung jawab menjadi guru profesional. Edukasi: Jurnal Pendidikan, 13(2), 161-174.

Farida, F. (2015). Pengembangan Model Pelatihan Partisipatif Berbasis Kompetensi Di Smk Panca Dharma Balikpapan (Doctoral dissertation, Universitas Negeri Makassar).

Fitria, H., Kristiawan, M., \& Rahmat, N. (2019). Upaya meningkatkan kompetensi guru melalui pelatihan penelitian tindakan kelas. Abdimas Unwahas, 4(1).

Hamdani, A. R., Inggriyani, F., \& Sukmaya, Y. (2018, December). Upaya Meningkatkan Kompetensi Guru Dalam Menyusun Proposal Penelitian Tindakan Kelas Melalui Model Pelatihan Partisipatif Dengan Pendampingan Intensif Di Uptd Pendidikan Kecamatan Sagalaherang Kabupaten Subang. In Seminar Nasional Pengabdian Kepada Masyarakat (PKM) (Vol. 1, No. 1, pp. 13-30).

Hanifah, N. (2014). Memahami penelitian tindakan kelas: teori dan aplikasinya. UPI Press.

Manizar, E. (2015). Peran guru sebagai motivator dalam belajar. Tadrib, 1(2), 204-222.

Mediatati, N., \& Ismanto, B. (2015, November). Peningkatan kompetensi menyusun proposal penelitian tindakan kelas melalui model pelatihan partisipatif dengan pendampingan intensif bagi guru guru di SMP Negeri 2 Ampel Kabupaten Boyolali. In Prosiding Seminar Pendidikan Ekonomi dan Bisnis (Vol. 1, No. 1).

Pianda, D. (2018). Kinerja guru: kompetensi guru, motivasi kerja dan kepemimpinan kepala sekolah. CV Jejak (Jejak Publisher).

Prihantoro, A., \& Hidayat, F. (2019). Melakukan Penelitian Tindakan Kelas. Ulumuddin: Jurnal Ilти-ilmu Keislaman, 9(1), 49-60. 
Sanjaya, D. H. W. (2016). Penelitian tindakan kelas. Prenada Media.

Zein, M. (2016). Peran guru dalam pengembangan pembelajaran. Jurnal Inspiratif Pendidikan, 5(2), 274-285. 